\title{
Article \\ Comparison of the Potential Ecological and Human Health Risks of Heavy Metals from Sewage Sludge and Livestock Manure for Agricultural Use
}

\author{
Baoling Duan and Qiang Feng * \\ College of Resources and Environment, Shanxi University of Finance and Economics, Taiyuan 030006, China; \\ sxcddbl@sxufe.edu.cn \\ * Correspondence: fengqiang@sxufe.edu.cn; Tel.: +86-351-7666149
}

check for

updates

Citation: Duan, B.; Feng, Q. Comparison of the Potential Ecological and Human Health Risks of Heavy Metals from Sewage Sludge and Livestock Manure for

Agricultural Use. Toxics 2021, 9, 145.

https://doi.org/10.3390/toxics9070145

Academic Editors:

Antoniadis Vasileios and Marc Amyot

Received: 27 April 2021

Accepted: 22 June 2021

Published: 24 June 2021

Publisher's Note: MDPI stays neutral with regard to jurisdictional claims in published maps and institutional affiliations.

Copyright: (c) 2021 by the authors. Licensee MDPI, Basel, Switzerland. This article is an open access article distributed under the terms and conditions of the Creative Commons Attribution (CC BY) license (https:/ / creativecommons.org/licenses/by/ $4.0 /)$.
Abstract: Sewage sludge and livestock (chicken, swine and cattle) manure samples were collected from the Yanmenguan Cattle Herbivorous Livestock Area to compare the potential ecological and human health risks caused by heavy metals contained in them. In this study, the Class II level of Quality Control of Imported Organic Fertilizers is selected as the limit standard value of heavy metals. Based on the mean content values, no heavy metal in cattle manure was higher than the limit standard value; the content of $\mathrm{Cu}$ in swine manure was higher than the limit of $\mathrm{Cu}$; the content of $\mathrm{Zn}$ in sewage sludge, chicken manure and swine manure were all higher than the limit of $\mathrm{Zn}$; and the content of $\mathrm{Cr}$ in sewage sludge and chicken manure were all higher than the limit of $\mathrm{Cr}$. Results indicated that sewage sludge and livestock manure all had high contents of $\mathrm{Zn}, \mathrm{Cu}$ and $\mathrm{Cr}$. The mean pollution index (PI) suggested that $\mathrm{Cu}, \mathrm{Zn}, \mathrm{As}$ and $\mathrm{Cr}$ in sewage sludge and livestock manures all induced potential ecological risks. According to the mean Nemerow's synthetic pollution index $(\mathrm{PN})$ values, swine manure had the highest potential ecological risk for agricultural use. Daily exposure to $\mathrm{Cu}, \mathrm{Zn}$ and $\mathrm{Cr}$ was higher than other heavy metals from sewage sludge and livestock manures, and heavy metal exposure was always higher for children than adults, with ingestion as the main pathway. Non-carcinogenic risk was caused mainly by $\mathrm{Cu}$ and $\mathrm{Cr}$, based on the higher hazard quotient $(\mathrm{HQ})$ values for adults and children. There was no non-carcinogenic risk for all people, except exposure of $\mathrm{Cu}$ from swine manure for children, which was 1.76 times higher than the threshold value of 1 . According to the mean hazard index (HI) values, only swine manure had a non-carcinogenic risk for children. As the carcinogenic risk index (Risk) values were continuously greater for As than $\mathrm{Cd}$, As had a higher carcinogenic risk than $\mathrm{Cd}$. There was no carcinogenic risk for any single heavy metal, although As exposure from sewage sludge was found to have an inapparent carcinogenic risk for both adults and children. Regarding the RISK value, sewage sludge had an unacceptable carcinogenic risk for adults and children, and swine manure had an unacceptable risk for children only. In general, for both non-carcinogenic and carcinogenic risks, ingestion was the main pathway, and children were more sensitive than adults. Comparing the four kinds of organic waste, cattle manure was the safest for agricultural use in terms of ecological and human health risks. In multiple comparisons, swine manure was significantly different regarding potential ecological risk and non-carcinogenic risk, and sewage sludge was significantly different regarding carcinogenic risk.

Keywords: organic waste; pollution index; health risk index; risk heavy metals; the Yanmenguan Cattle Herbivorous Livestock Area

\section{Introduction}

Sewage sludge and livestock manure are rich in nutrients, such as organic matter, nitrogen, phosphorus, and potassium, which are necessary for plant growth and improved crop yields [1,2]. Hence, sewage sludge and livestock manure are widely used in agriculture around the world and are recommended as land fertilizer by the government of China $[3,4]$. 
In Shanxi, $42.66 \%$ of sewage sludge is disposed of by land use as soil conditioners or fertilizers, and $87.8 \%$ of livestock manure is directly returned to nearby fields $[4,5]$.

The way sewage sludge and livestock manure are used as soil conditioners is regarded as a method of waste recycling, and it is the most economical means for handling this waste [1,6-8]. However, in addition to the advantages of the nutritious substances contained in sewage sludge and livestock manure that can increase plant yield and improve soil properties, the toxic materials they contain, especially heavy metals, also enter into the soil [6,8-10]. In the process of wastewater treatment, $50-80 \%$ of heavy metals are transferred into sewage sludge [11]. In addition, most heavy metals are excreted in livestock manure; large quantities of them are added to fodder to prevent diseases and improve the growth of livestock, but their usage is low $[12,13]$. Due to its non-biodegradability, persistence and toxicity, the agricultural use of sewage sludge and livestock manure causes heavy metal pollution of the soil environment [14-17]. Furthermore, heavy metals in sewage sludge and livestock manure will not only enter into the soil, but also other ecosystems, such as the atmosphere, groundwater, surface water and biosphere, as all ecosystems are mutually connected [1,18-20]. Therefore, using sewage sludge and livestock manure as a soil fertilizer will not only potentially cause ecological risk to the ecosystem, but also pose a threat to human health through groundwater, the human food chain and other ecosystems $[16,18,19,21]$. Heavy metal has become a critical factor in the agricultural use of sewage sludge and livestock manure [22].

In order to prevent the adverse effects of the agricultural use of sewage sludge and livestock manure induced by heavy metals, potential ecological and human health risks must be assessed $[23,24]$. The assessment of the potential ecological risks of heavy metals commonly uses the geo-accumulation index, single-factor pollution index, Nemerow's synthetic pollution index, and ecological risk index [25-28]. Most of the assessments of the human health risks of heavy metals basically adopt the exposure models formulated by the United Stated Environmental Protection Agency (US EPA). However, there are fewer studies comparing the potential ecological and human health risks between sewage sludge and livestock manure. In addition, human health risk assessment often focuses on adults, but children should receive special attention in health risk assessment due to their low tolerance to toxins and inadvertent behavior like ingestion, putting them in contact with significant quantities of sewage sludge and livestock manure. In this study, in order to assess the differences between sewage sludge and livestock manure in terms of the risks they pose to environment and human health, a comparison was performed.

The aims of this present study were as follows: (a) to identify the concentration of heavy metals in sewage sludge and livestock manure sampled from the Yanmenguan Cattle Herbivorous Livestock Area in the north of Shanxi; (b) to assess the potential ecological risks of heavy metals in sewage sludge and livestock manure and compare the differences; (c) to evaluate heavy metal exposure from sewage sludge and livestock manure and distinguish the difference in exposure of adults and children; and (d) to identify and compare non-carcinogenic and carcinogenic risk between sewage and livestock manure for adults and children.

\section{Materials and Methods}

\subsection{Sampling and Chemical Analysis}

Sewage sludge and livestock manure (chicken, swine, and cattle) were sampled from the Yanmenguan Cattle Herbivorous Livestock Area, north of Shanxi, China. Sewage sludge was collected from five municipal wastewater treatment plants with the largest production in the study area; for chicken, swine, and cattle manure, five, six, and seven samples, respectively, were collected from intensive livestock farms. To enhance the sample's representativeness, four subsamples were collected from four different sites in the storage pile at each wastewater treatment plant and four different sites in the manure storage area at each farm. Then, the four subsamples were blended together as one sample. 
At room temperature, samples were air-dried in a clean environment, sieved through a mesh with a pore size of $0.14 \mathrm{~mm}$, and then placed in brown glass bottles. Samples were weighed and digested with $\mathrm{HNO}_{3}$ using a microwave digestion system based on US EPA Method 3051B [29]. Cu, Zn, Pb, and Cr were analyzed using an atomic absorption spectrophotometer; $\mathrm{Cd}$ was analyzed using a graphite furnace atomic absorption spectrophotometer; and As was analyzed using an atomic fluorescence spectrometer. The Chinese national standards GB/T 15555.2-1995, GB/T 15555.2-1995, GB/T 15555.2-1995, GB/T 15555.6-1996, GB/T 17141-1997, and GB/T 22105.2-2008 were used to perform chemical analysis, and solutions used for the calibration of the instruments were implemented in these standards. Certified reference material was also used to control the quality. Accuracy, precision and recovery were checked by testing the certified reference material. The method detection limit was confirmed by testing blind samples 11 times. When each batch of samples was tested, two blank samples and reference samples were detected at the same time. Triplicate samples were determined, and then the mean value of the result was the final concentration of heavy metals. Results are shown in Table 1.

Table 1. Analytical accuracy, precision, recovery and method detection limit.

\begin{tabular}{cccccccc}
\hline $\begin{array}{c}\text { Heavy } \\
\text { Metal }\end{array}$ & $\begin{array}{c}\text { Confidence } \\
\text { Interval } \\
(\mathbf{m g} / \mathbf{k g})\end{array}$ & $\begin{array}{c}\text { Certified } \\
\text { Value } \\
(\mathbf{m g} / \mathbf{k g})\end{array}$ & $\begin{array}{c}\text { Measured } \\
\text { Value } \\
(\mathbf{m g} / \mathbf{k g})\end{array}$ & $\begin{array}{c}\text { Accuracy } \\
\mathbf{( \% )}\end{array}$ & $\begin{array}{c}\text { Precision } \\
\mathbf{( \% )}\end{array}$ & $\begin{array}{c}\text { Mecovery } \\
\mathbf{( \% )}\end{array}$ & $\begin{array}{c}\text { Detection Limit } \\
(\mathbf{m g} / \mathbf{k g})\end{array}$ \\
\hline $\mathrm{Cu}$ & $433-531$ & 482 & 470.96 & 3.68 & -2.29 & 94.61 & 0.907 \\
$\mathrm{Zn}$ & $1060-1420$ & 1240 & 1229.59 & 5.02 & -0.84 & 94.51 & 0.984 \\
$\mathrm{Cd}$ & $56.9-64.2$ & 60 & 63.01 & 1.43 & 5.01 & -4.03 & 92.77 \\
$\mathrm{~Pb}$ & $143-165$ & 154 & 147.79 & 3.38 & -2.96 & 95.25 & 0.318 \\
$\mathrm{As}$ & $202-256$ & 229 & 222.21 & 3.35 & -2.67 & 93.12 \\
$\mathrm{Cr}$ & $259-319$ & 289 & 281.29 & 4.25 & & 4.387 \\
\hline
\end{tabular}

\subsection{Ecological Risk Assessment}

The single-factor pollution index (PI) was developed and used to assess the contamination of a single heavy metal, and it was evaluated to express the pollution level by comparing with standard values. It is defined as the following equation $[30,31]$ :

$$
\mathrm{PI}=\mathrm{C}_{\mathrm{i}} / \mathrm{S}_{\mathrm{i}}
$$

where PI is the single-factor pollution index of the ith heavy metal, $C_{i}$ is the concentration of the ith heavy metal $(\mathrm{mg} / \mathrm{kg})$ in sewage sludge and livestock manure, and $S_{i}$ is the limit standard value of the ith heavy metal $(\mathrm{mg} / \mathrm{kg})$. In this paper, $S_{i}$ is represented by the Class II of Quality Control of Imported Organic Fertilizers; the corresponding standard values $\left(\mathrm{S}_{\mathrm{i}}\right)$ for $\mathrm{Cu}, \mathrm{Zn}, \mathrm{Cd}, \mathrm{Pb}$, As and $\mathrm{Cr}$ are 300, 300, 1.0, 100, 10 and $100 \mathrm{mg} / \mathrm{kg}$, respectively [32]. The contamination level of heavy metals is classified into five grades based on the PI value: no contamination: $\mathrm{PI} \leq 1.0$; low contamination: $1.0<\mathrm{PI} \leq 2.0$; moderate contamination: $2.0<\mathrm{PI} \leq 3.0$; strong contamination: $3.0<\mathrm{PI} \leq 5.0$; and very strong contamination: PI $>5.0[30,31]$.

To assess the synthetic pollution of all heavy metals, Nemerow's synthetic pollution index (PN) was used, and the equation is as follows [33]:

$$
\mathrm{PN}=\sqrt{\frac{\mathrm{P}_{\mathrm{i}, \mathrm{ave}}^{2}+\mathrm{P}_{\mathrm{i}, \mathrm{max}}^{2}}{2}}
$$

where $\mathrm{PN}$ is the synthetic pollution index, $\mathrm{P}_{\mathrm{i}, \text { ave }}$ is the average value of the single-factor pollution index of the ith heavy metal, and $P_{i, \max }$ is the maximum value of the single-factor pollution index of the ith heavy metal. According to the PN value, the pollution level can be divided into 5 classes: safe: $\mathrm{PN} \leq 0.7$; warning line of pollution: $0.7<\mathrm{PN} \leq 1.0$; slight 
pollution: $1.0<\mathrm{PN} \leq 2.0$; moderate pollution: $2.0<\mathrm{PN} \leq 3.0$; and heavy pollution: $\mathrm{PN}>$ $3.0[31,34]$.

PI and PN focus on different aspects of toxic element pollution: PI expresses the pollution situation of one single heavy metal, and PN emphasizes contamination caused by the total of heavy metals in the environment, and it synthesizes not only their average level, but also their maximum level [35].

\subsection{Human Health Risk Assessment}

Human health risk assessment involves the interaction of environmental pollutants and human health. It can be considered as a quantitative description of the risk that environmental pollutants will cause harm to human health [36]. Based on the US EPA Part 503 rule, heavy metal exposure in humans has two pathways, ingestion and inhalation [37]. According to the International Agency for Research on Cancer (IARC) and the World Health Organization (WHO), Cd and As are classified as carcinogenic pollutants [38,39].

\subsubsection{Exposure Assessment}

Human exposure to heavy metals is expressed as an average daily dose (ADD), based on the health risk model recommended by the US EPA, determined by the following equations [40-43]:

$$
\begin{gathered}
\mathrm{ADD}=\mathrm{ADD}_{\text {ingest }}+\mathrm{ADD} \text { inhale } \\
\mathrm{ADD}_{\text {ingest }}=\frac{\mathrm{C} \times \mathrm{IR}_{\text {ingest }} \times \mathrm{EF} \times \mathrm{ED}}{\mathrm{BW} \times \mathrm{AT}} \times \mathrm{CF} \\
\mathrm{ADD}_{\text {inhale }}=\frac{\mathrm{C} \times \operatorname{Inh} \mathrm{R} \times \mathrm{EF} \times \mathrm{ED}}{\mathrm{PEF} \times \mathrm{BW} \times \mathrm{AT}}
\end{gathered}
$$

where $\mathrm{ADD}_{\text {ingest }}$ is the average daily dose for ingestion $\left(\mathrm{mg} \cdot \mathrm{kg}^{-1} \cdot \mathrm{day}^{-1}\right) ; \mathrm{ADD}_{\text {inhale }}$ is the average daily dose for inhalation $\left(\mathrm{mg} \cdot \mathrm{kg}^{-1} \cdot \mathrm{day}^{-1}\right)$; ADD is the average daily total exposure dose $\left(\mathrm{mg} \cdot \mathrm{kg}^{-1}\right)$; $\mathrm{C}$ is the concentration of heavy metals in sewage sludge and livestock manure $\left(\mathrm{mg} \cdot \mathrm{kg}^{-1}\right)$; $\mathrm{IR}_{\text {ingest }}$ is the ingestion rate of heavy metals, which is $100 \mathrm{mg} \cdot \mathrm{day}^{-1}$ for adults and $200 \mathrm{mg} \cdot \mathrm{day}^{-1}$ for children [44]; EF is the exposure frequency, with 350 days.year ${ }^{-1}$ [44]; ED is the exposure duration, which is 30 years for adults and 6 years for children; BW is average body weight, which is $70 \mathrm{~kg}$ for adults and $16 \mathrm{~kg}$ for children [37]; AT is the average time, and for non-carcinogens is equal to $\mathrm{ED} \times 365$ days and for carcinogens is equal to 70 years (lifetime) $\times 365$ days [44]; CF is a conversion factor $\left(1 \times 10^{-6}\right)$; InhR is the inhalation rate [44], and is $7.6 \mathrm{~m}^{3} \cdot \mathrm{day}^{-1}$ for children and $20 \mathrm{~m}^{3} \cdot$ day $^{-1}$ for adults [34]; and PEF is the particle emission factor $\left(1.36 \times 109 \mathrm{~m}^{3} \cdot \mathrm{kg}^{-1}\right)$ [43].

\subsubsection{Non-Carcinogenic Risk Assessment}

The hazard quotient $(\mathrm{HQ})$ was applied to estimate the non-carcinogenic risk of a single heavy metal, using the following equation [40,45]:

$$
\mathrm{HQ}_{\mathrm{ij}}=\frac{\mathrm{ADD}_{\mathrm{ij}}}{\operatorname{RfD}_{\mathrm{ij}}}
$$

where $\mathrm{HQ}_{\mathrm{ij}}$ is the hazard quotient of the ith heavy metal via the jth pathway; $\mathrm{ADD}_{\mathrm{ij}}$ is the average daily dose for the ith heavy metal via the jth pathway $\left(\mathrm{mg} \cdot \mathrm{kg}^{-1} \cdot\right.$ day $\left.^{-1}\right)$; and $\mathrm{RfD}_{\mathrm{ij}}$ is the risk reference dose of the ith heavy metal via the jth pathway $\left(\mathrm{mg} \cdot \mathrm{kg}^{-1} \cdot \mathrm{day}^{-1}\right)$. The $\mathrm{RfD}$ values of $\mathrm{Cu}, \mathrm{Zn}, \mathrm{Pb}$ and $\mathrm{Cr}$ via ingestion and inhalation are the same: $0.004,0.300$, 0.038 and $0.005 \mathrm{mg} \cdot \mathrm{kg}^{-1} \cdot \mathrm{day}^{-1}$, respectively [39].

In order to assess the total non-carcinogenic risk of human exposure to different heavy metals through different pathways, the hazard index (HI) is introduced, using the following equation [46]:

$$
\mathrm{HI}=\sum_{\mathrm{i}=1}^{\mathrm{n}} \sum_{\mathrm{j}=1}^{\mathrm{m}} \mathrm{HQ}_{\mathrm{ij}}
$$


If $\mathrm{HQ}<1$ or $\mathrm{HI}<1$, there is no significant non-carcinogenic risk, which can be ignored; if $\mathrm{HQ}>1$ or $\mathrm{HI}>1$, there is significant non-carcinogenic risk, which will increase with increasing values of $\mathrm{HQ}$ or $\mathrm{HI}[40-42]$.

\subsubsection{Carcinogenic Risk Assessment}

For individuals who are exposed to potential carcinogenic pollutants, the possibility of developing cancer in their lifetime is considered carcinogenic risk. It is represented by the carcinogenic risk index (Risk) with the following equation [38,40,41]:

$$
\mathrm{RISK}_{\mathrm{ij}}=\mathrm{ADD}_{\mathrm{ij}} \times \mathrm{SF}
$$

where Risk $\mathrm{ij}_{\mathrm{ij}}$ is the carcinogenic risk index of the ith heavy metal via the jth pathway and SF is the carcinogenic slope factor $\left(\mathrm{kg} \cdot\right.$ day $\left.\cdot \mathrm{mg}^{-1}\right)$. The SF values of As and Cd via ingestion and inhalation are the same: 1.5 and $6.1 \mathrm{~kg} \cdot$ day $\cdot \mathrm{mg}^{-1}$, respectively [39].

In order to assess the total carcinogenic risk of human exposure to $\mathrm{As}$ and $\mathrm{Cd}$, the sum of the risk of all heavy metals is expressed as RISK and the equation is as follows [46]:

$$
\text { RISK }=\sum_{i=1}^{n} \sum_{j=1}^{m} \operatorname{Risk}_{i j}
$$

If Risk $<1 \times 10^{-6}$, there is no carcinogenic risk; if $1 \times 10^{-6}<$ Risk $<1 \times 10^{-4}$, there is an inapparent carcinogenic risk, and the risk is acceptable; if Risk $>1 \times 10^{-4}$, there is significant carcinogenic risk, and the risk is unacceptable. For total heavy metals via the two pathways, if RISK $<1 \times 10^{-5}$, the carcinogenic risk is acceptable, and if RISK $>1 \times 10^{-5}$, the carcinogenic risk is unacceptable $[39,40,46]$. Then, we applied one-way analysis of variance (one-way ANOVA) and the Duncan method for multiple comparisons to analyze different significance of heavy metal indices from different sources.

\section{Results}

\subsection{Heavy Metal Concentration in Sewage Sludge and Livestock Manure}

The heavy metal content in sewage sludge and different kinds of livestock manure was determined and is presented in Table 2. According to the mean values of concentration, heavy metals were ranked in decreasing order as follows: $\mathrm{Zn}>\mathrm{Cr}>\mathrm{Cu}>\mathrm{Pb}>\mathrm{As}>\mathrm{Cd}$ for sewage sludge and chicken manure; $\mathrm{Zn}>\mathrm{Cu}>\mathrm{Cr}>\mathrm{As}>\mathrm{Pb}>\mathrm{Cd}$ for swine manure; and $\mathrm{Zn}>\mathrm{Cu}>\mathrm{Cr}>\mathrm{Pb}>\mathrm{As}>\mathrm{Cd}$ for cattle manure. Not only in sewage sludge but also in livestock manures, $\mathrm{Zn}, \mathrm{Cu}$, and $\mathrm{Cr}$ contents were higher.

Table 2. Contents of heavy metals in sewage sludge and livestock manure $\left(\mathrm{mg} \cdot \mathrm{kg}^{-1}\right)$.

\begin{tabular}{ccccccc}
\hline Organic Waste & $\mathbf{C u}$ & $\mathbf{Z n}$ & $\mathbf{C d}$ & $\mathbf{P b}$ & $\mathbf{A s}$ & $\mathbf{C r}$ \\
\hline Sewage sludge & $75.96 \pm 17.46 \mathrm{a}$ & $380.54 \pm 209.81 \mathrm{~b}$ & $0.78 \pm 0.16 \mathrm{~b}$ & $20.16 \pm 2.58 \mathrm{~b}$ & $15.67 \pm 5.18 \mathrm{~b}$ & $180.51 \pm 35.45 \mathrm{~b}$ \\
Chicken manure & $85.43 \pm 38.57 \mathrm{a}$ & $395.43 \pm 139.96 \mathrm{~b}$ & $0.31 \pm 0.05 \mathrm{a}$ & $6.36 \pm 4.41 \mathrm{a}$ & $2.73 \pm 2.26 \mathrm{a}$ & $153.66 \pm 176.95 \mathrm{~b}$ \\
Swine manure & $588.32 \pm 315.12 \mathrm{~b}$ & $933.33 \pm 336.28 \mathrm{c}$ & $0.33 \pm 0.08 \mathrm{a}$ & $5.65 \pm 3.39 \mathrm{a}$ & $6.03 \pm 5.17 \mathrm{a}$ & $21.86 \pm 136.62 \mathrm{a}$ \\
Cattle manure & $41.16 \pm 27.27 \mathrm{a}$ & $119.52 \pm 104.11 \mathrm{a}$ & $0.26 \pm 0.05 \mathrm{a}$ & $13.72 \pm 15.28 \mathrm{a}$ & $2.59 \pm 1.21 \mathrm{a}$ & $24.47 \pm 34.57 \mathrm{a}$ \\
\hline
\end{tabular}

Different lower-case letters indicate the results of multiple comparisons between different organic waste.

The $\mathrm{Cd}, \mathrm{Pb}$, As and $\mathrm{Cr}$ content in sewage sludge is much higher than that in livestock manure, except for $\mathrm{Cr}$ in chicken manure, which is almost equal to that in sewage sludge. Furthermore, multiple comparisons indicated that sewage sludge was significantly different from livestock manure regarding the content of $\mathrm{Cd}, \mathrm{Pb}$, As and $\mathrm{Cr}$, but not significantly different from chicken manure regarding the content of $\mathrm{Cr}$. The highest $\mathrm{Cu}$ and $\mathrm{Zn}$ contents were found in swine manure, the second highest in chicken manure and the lowest in cattle manure. In the multiple comparisons, swine manure was significantly different from other organic waste regarding the content of $\mathrm{Cu}$ and $\mathrm{Zn}$. This is due to the fact that in the breeding process, large amounts of $\mathrm{Cu}$ and $\mathrm{Zn}$ are added to the fodder, but are often less used by animals and not easy to decompose, so they are excreted in the manure [47]. Cattle 
manure contains the lowest amount of $\mathrm{Cu}$ and $\mathrm{Zn}$, which may be due to the fact that cattle are mainly fed with silage and grass [48,49].

As shown in Table 3, the heavy metal limits formulated by different countries for agricultural use of sewage sludge are generally the same, except Canada has more rigid standards than other countries [50]. Around the world, although there are no special limits on heavy metals for organic waste, some European countries, such as Belgium, the Netherlands and Germany, have strict limits on heavy metals in compost [51]. In China, the standards for heavy metals in organic fertilizers, such as Control Standards for Urban Wastes for Agricultural Use (GB8172-87), Technical Specification for Animal Manure Composting (NY/T 3442-2019), and Organic Fertilizer (NY525-2012), were all lack of Cu and $\mathrm{Zn}$ indices. Compared with the compost standard, the heavy metal content limits are more relaxed for the agricultural use of sewage sludge. Hence, the Class II level of Quality Control Standards of Imported Organic Fertilizers was adopted in this study.

Table 3. Heavy metal limits in sewage sludge and livestock manure for different criteria $\left(\mathrm{mg} \cdot \mathrm{kg}^{-1}\right)$.

\begin{tabular}{|c|c|c|c|c|c|c|}
\hline Organic Waste & $\mathrm{Cu}$ & Zn & $\mathrm{Cd}$ & $\mathrm{Pb}$ & As & $\mathrm{Cr}$ \\
\hline \multicolumn{7}{|l|}{ Sewage sludge } \\
\hline US EPA & 1500 & 2800 & 39 & 300 & 41 & 1200 \\
\hline $\begin{array}{c}\text { European Union } \\
\text { Directive 86/278/EEC }\end{array}$ & $1000-1750$ & $2500-4000$ & $20-40$ & $750-1200$ & - & - \\
\hline Denmark & 1000 & 4000 & 0.8 & 120 & 25 & 100 \\
\hline Netherlands & 75 & 300 & 1.25 & 100 & 15 & 75 \\
\hline Canada & 500 & 2000 & 20 & 200 & 10 & 1000 \\
\hline \multicolumn{7}{|l|}{ GB4284-84 } \\
\hline $\mathrm{pH}<6.5$ & 1500 & 3000 & 20 & 1000 & 75 & 1000 \\
\hline $\mathrm{pH} \geq 6.5$ & 800 & 2000 & 5 & 300 & 75 & 600 \\
\hline \multicolumn{7}{|l|}{ Fertilizers } \\
\hline GB8172-87 & - & - & 3 & 100 & 30 & 300 \\
\hline NY/T 3442-2019 & - & - & 3 & 50 & 15 & 150 \\
\hline NY525-2012 & - & - & 3 & 50 & 15 & 150 \\
\hline \multicolumn{7}{|c|}{$\begin{array}{l}\text { Quality Control Standards of } \\
\text { Imported Organic Fertilizers }\end{array}$} \\
\hline Class I & 100 & 200 & 0.6 & 50 & 5 & 50 \\
\hline Class II & 300 & 300 & 1.0 & 100 & 10 & 100 \\
\hline
\end{tabular}

Compared with the threshold values, the contents of $\mathrm{Cd}$ and $\mathrm{Pb}$ in all samples were lower. The mean contents of $\mathrm{Zn}$, As and $\mathrm{Cr}$ for sewage sludge, $\mathrm{Zn}$ and $\mathrm{Cr}$ for chicken manure, $\mathrm{Cu}$ and $\mathrm{Zn}$ for swine manure and no heavy metals for cattle manure were higher than the limit values.

\subsection{Potential Ecological Risk Assessment}

The assessment of potential ecological risks of sewage sludge and livestock manure are shown in Table 4. Zn, As and $\mathrm{Cr}$ in sewage sludge, $\mathrm{Zn}$ and $\mathrm{Cr}$ in chicken manure and $\mathrm{Cu}$ in swine manure all had low levels of contamination, based on PI values higher than $1 ; \mathrm{Zn}$ in swine manure had a higher level of contamination according to its mean PI value being higher than 3 . The results show that the potential ecological risk of sewage sludge and livestock manure mainly involved $\mathrm{Zn}$ and $\mathrm{Cr}$. Multiple comparisons indicated that the potential ecological risk caused by swine manure was significantly different from other organic waste regarding $\mathrm{Cu}$ and $\mathrm{Zn}$; the ecological risk induced by sewage sludge was significantly different regarding $\mathrm{Cd}, \mathrm{Pb}$ and $\mathrm{As}$; regarding $\mathrm{Cr}$, sewage sludge and chicken manure showed no significant difference, and swine manure and cattle manure were the same, but they showed significant differences between them. $\mathrm{Zn}$ and $\mathrm{Cr}$ pollution in sewage sludge was caused by industrial production, and in livestock manure by feed supplementation and the animal's metabolic characteristics (low usage and high excretion 
of heavy metals) [12,49]. Based on the mean PN values, the pollution severity ranking of sewage sludge and livestock manure was swine manure $>$ chicken manure $>$ sewage sludge $>$ cattle manure. In the multiple comparisons, swine manure was significantly different from other organic waste; chicken manure and sewage sludge had no significant difference. In addition, the mean PN value for swine manure was higher than three, indicating that pig manure had heavy pollution for agricultural use; the mean PN values for sewage sludge and chicken manure were higher than two, showing that these had moderate pollution; and for cattle manure, the value was lower than 0.7, showing that it was safe for land use. These results suggested that sewage sludge, chicken manure and swine manure all had dangerous levels of heavy metals and should undergo more scrutiny for agricultural use.

Table 4. Results of single-factor pollution index (PI) and Nemerow's synthetic pollution index (PN) for heavy metals in agricultural use of sewage sludge and livestock manure.

\begin{tabular}{cccccccc}
\hline Organic Waste & $\mathbf{P I}_{\mathbf{C u}}$ & $\mathbf{P I}_{\mathbf{Z n}}$ & $\mathbf{P I}_{\mathbf{C d}}$ & $\mathbf{P I}_{\mathbf{P b}}$ & $\mathbf{P I}_{\mathbf{A s}}$ & $\mathbf{P I}_{\mathbf{C r}}$ & $\mathbf{P N}$ \\
\hline Sewage sludge & $0.25 \mathrm{a}$ & $1.27 \mathrm{~b}$ & $0.78 \mathrm{~b}$ & $0.20 \mathrm{~b}$ & $1.57 \mathrm{~b}$ & $1.81 \mathrm{~b}$ & $2.19 \mathrm{~b}$ \\
Chicken manure & $0.28 \mathrm{a}$ & $1.32 \mathrm{~b}$ & $0.31 \mathrm{a}$ & $0.06 \mathrm{a}$ & $0.27 \mathrm{a}$ & $1.54 \mathrm{~b}$ & $2.36 \mathrm{~b}$ \\
Swine manure & $1.96 \mathrm{~b}$ & $3.11 \mathrm{c}$ & $0.33 \mathrm{a}$ & $0.06 \mathrm{a}$ & $0.60 \mathrm{a}$ & $0.22 \mathrm{a}$ & $3.47 \mathrm{c}$ \\
Cattle manure & $0.14 \mathrm{a}$ & $0.40 \mathrm{a}$ & $0.26 \mathrm{a}$ & $0.14 \mathrm{a}$ & $0.26 \mathrm{a}$ & $0.24 \mathrm{a}$ & $0.52 \mathrm{a}$ \\
\hline
\end{tabular}

Different lower-case letters indicate the results of multiple comparisons between different organic waste.

\subsection{Health Risk Assessment}

\subsubsection{Exposure Assessment}

Daily exposure to heavy metals in sewage sludge and livestock manure was quantified based on the method recommended by the US EPA. The exposure rates for adults and children were compared, as shown in Table 5.

Table 5. Average daily dose (ADD) of heavy metals in sewage sludge and livestock manure $\left(\mathrm{mg} \cdot \mathrm{kg}^{-1} \cdot \mathrm{day}^{-1}\right)$.

\begin{tabular}{|c|c|c|c|c|c|c|c|c|}
\hline Kinds & Index & Organic Waste & $\mathrm{Cu}$ & Zn & $\mathrm{Cd}$ & $\mathbf{P b}$ & As & $\mathrm{Cr}$ \\
\hline \multirow{12}{*}{ Adults } & \multirow{4}{*}{$\mathrm{ADD}_{\text {ingest }}$} & Sewage sludge & $1.04 \times 10^{-4} \mathrm{a}$ & $5.21 \times 10^{-4} \mathrm{~b}$ & $4.60 \times 10^{-7} \mathrm{~b}$ & $2.76 \times 10^{-5} \mathrm{~b}$ & $9.20 \times 10^{-6} \mathrm{~b}$ & $2.47 \times 10^{-4} \mathrm{~b}$ \\
\hline & & Chicken manure & $1.17 \times 10^{-4} \mathrm{a}$ & $5.42 \times 10^{-4} \mathrm{~b}$ & $1.83 \times 10^{-7} \mathrm{a}$ & $8.72 \times 10^{-6} \mathrm{a}$ & $1.60 \times 10^{-6} \mathrm{a}$ & $2.10 \times 10^{-4} \mathrm{~b}$ \\
\hline & & Swine manure & $8.06 \times 10^{-4} \mathrm{~b}$ & $1.28 \times 10^{-3} \mathrm{c}$ & $1.92 \times 10^{-7} \mathrm{a}$ & $7.73 \times 10^{-6} \mathrm{a}$ & $3.54 \times 10^{-6} \mathrm{a}$ & $2.99 \times 10^{-5} \mathrm{a}$ \\
\hline & & Cattle manure & $5.64 \times 10^{-5} \mathrm{a}$ & $1.64 \times 10^{-4} \mathrm{a}$ & $1.54 \times 10^{-7} \mathrm{a}$ & $1.88 \times 10^{-5} \mathrm{a}$ & $1.52 \times 10^{-6} \mathrm{a}$ & $3.35 \times 10^{-5} \mathrm{a}$ \\
\hline & \multirow{4}{*}{$\mathrm{ADD}_{\text {inhale }}$} & Sewage sludge & $1.53 \times 10^{-8} \mathrm{a}$ & $7.67 \times 10^{-8} \mathrm{~b}$ & $6.76 \times 10^{-11} \mathrm{~b}$ & $4.06 \times 10^{-9} \mathrm{~b}$ & $1.35 \times 10^{-9} \mathrm{~b}$ & $3.64 \times 10^{-8} \mathrm{~b}$ \\
\hline & & Chicken manure & $1.72 \times 10^{-8} \mathrm{a}$ & $7.97 \times 10^{-8} \mathrm{~b}$ & $2.69 \times 10^{-11} \mathrm{a}$ & $1.28 \times 10^{-9} \mathrm{a}$ & $2.36 \times 10^{-10} \mathrm{a}$ & $3.10 \times 10^{-8} \mathrm{~b}$ \\
\hline & & Swine manure & $1.19 \times 10^{-7} \mathrm{~b}$ & $1.88 \times 10^{-7} \mathrm{c}$ & $2.82 \times 10^{-11} \mathrm{a}$ & $1.14 \times 10^{-9} \mathrm{a}$ & $5.21 \times 10^{-10} \mathrm{a}$ & $4.40 \times 10^{-9} \mathrm{a}$ \\
\hline & & Cattle manure & $8.29 \times 10^{-9} \mathrm{a}$ & $2.41 \times 10^{-8} \mathrm{a}$ & $2.27 \times 10^{-11} \mathrm{a}$ & $2.76 \times 10^{-9} \mathrm{a}$ & $2.23 \times 10^{-10} \mathrm{a}$ & $4.93 \times 10^{-9} \mathrm{a}$ \\
\hline & \multirow{4}{*}{ ADD } & Sewage sludge & $1.04 \times 10^{-4} \mathrm{a}$ & $5.21 \times 10^{-4} \mathrm{~b}$ & $4.60 \times 10^{-7} \mathrm{~b}$ & $2.76 \times 10^{-5} \mathrm{~b}$ & $9.20 \times 10^{-6} \mathrm{~b}$ & $2.47 \times 10^{-4} \mathrm{~b}$ \\
\hline & & Chicken manure & $1.17 \times 10^{-4} \mathrm{a}$ & $5.42 \times 10^{-4} \mathrm{~b}$ & $1.83 \times 10^{-7} \mathrm{a}$ & $8.72 \times 10^{-6} \mathrm{a}$ & $1.60 \times 10^{-6} \mathrm{a}$ & $2.11 \times 10^{-4} \mathrm{~b}$ \\
\hline & & Swine manure & $8.06 \times 10^{-4} \mathrm{~b}$ & $1.28 \times 10^{-3} \mathrm{c}$ & $1.92 \times 10^{-7} \mathrm{a}$ & $7.73 \times 10^{-6} \mathrm{a}$ & $3.54 \times 10^{-6} \mathrm{a}$ & $2.99 \times 10^{-5} \mathrm{a}$ \\
\hline & & Cattle manure & $5.64 \times 10^{-5} \mathrm{a}$ & $1.64 \times 10^{-4} \mathrm{a}$ & $1.54 \times 10^{-7} \mathrm{a}$ & $1.88 \times 10^{-5} \mathrm{a}$ & $1.52 \times 10^{-6} \mathrm{a}$ & $3.35 \times 10^{-5} \mathrm{a}$ \\
\hline \multirow{12}{*}{ Children } & \multirow{4}{*}{$\mathrm{ADD}_{\text {ingest }}$} & Sewage sludge & $9.11 \times 10^{-4} \mathrm{a}$ & $4.56 \times 10^{-3} \mathrm{~b}$ & $8.05 \times 10^{-7} \mathrm{~b}$ & $2.42 \times 10^{-4} \mathrm{~b}$ & $1.61 \times 10^{-5} \mathrm{~b}$ & $2.16 \times 10^{-3} \mathrm{~b}$ \\
\hline & & Chicken manure & $1.02 \times 10^{-3} \mathrm{a}$ & $4.74 \times 10^{-3} \mathrm{~b}$ & $3.20 \times 10^{-7} \mathrm{a}$ & $7.63 \times 10^{-5} \mathrm{a}$ & $2.81 \times 10^{-6} \mathrm{a}$ & $1.84 \times 10^{-3} \mathrm{~b}$ \\
\hline & & Swine manure & $7.05 \times 10^{-3} \mathrm{~b}$ & $1.12 \times 10^{-2} \mathrm{c}$ & $3.36 \times 10^{-7} \mathrm{a}$ & $6.77 \times 10^{-5} \mathrm{a}$ & $6.20 \times 10^{-6} a$ & $2.62 \times 10^{-4} \mathrm{a}$ \\
\hline & & Cattle manure & $4.93 \times 10^{-4} \mathrm{a}$ & $1.43 \times 10^{-3} \mathrm{a}$ & $2.70 \times 10^{-7} \mathrm{a}$ & $1.64 \times 10^{-4} \mathrm{a}$ & $2.66 \times 10^{-6} \mathrm{a}$ & $2.93 \times 10^{-4} \mathrm{a}$ \\
\hline & \multirow{4}{*}{$\mathrm{ADD}_{\text {inhale }}$} & Sewage sludge & $2.54 \times 10^{-8} \mathrm{a}$ & $1.27 \times 10^{-7} \mathrm{~b}$ & $2.25 \times 10^{-11} \mathrm{~b}$ & $6.75 \times 10^{-9} \mathrm{~b}$ & $4.50 \times 10^{-10} \mathrm{~b}$ & $6.05 \times 10^{-8} \mathrm{~b}$ \\
\hline & & Chicken manure & $2.86 \times 10^{-8} \mathrm{a}$ & $1.32 \times 10^{-7} \mathrm{~b}$ & $8.94 \times 10^{-12} \mathrm{a}$ & $2.13 \times 10^{-9} \mathrm{a}$ & $7.84 \times 10^{-11} \mathrm{a}$ & $5.15 \times 10^{-8} \mathrm{~b}$ \\
\hline & & Swine manure & $1.97 \times 10^{-7} \mathrm{~b}$ & $3.13 \times 10^{-7} \mathrm{c}$ & $9.39 \times 10^{-12} \mathrm{a}$ & $1.89 \times 10^{-9} \mathrm{a}$ & $1.73 \times 10^{-10} \mathrm{a}$ & $7.32 \times 10^{-9} \mathrm{a}$ \\
\hline & & Cattle manure & $1.38 \times 10^{-8} \mathrm{a}$ & $4.00 \times 10^{-8} \mathrm{a}$ & $7.54 \times 10^{-12} \mathrm{a}$ & $4.60 \times 10^{-9} \mathrm{a}$ & $7.42 \times 10^{-11} \mathrm{a}$ & $8.20 \times 10^{-9} \mathrm{a}$ \\
\hline & \multirow{4}{*}{ ADD } & Sewage sludge & $9.11 \times 10^{-4} \mathrm{a}$ & $4.56 \times 10^{-3} \mathrm{~b}$ & $8.05 \times 10^{-7} \mathrm{~b}$ & $2.42 \times 10^{-4} \mathrm{~b}$ & $1.61 \times 10^{-5} \mathrm{~b}$ & $2.16 \times 10^{-3} \mathrm{~b}$ \\
\hline & & Chicken manure & $1.02 \times 10^{-3} \mathrm{a}$ & $4.74 \times 10^{-3} \mathrm{~b}$ & $3.20 \times 10^{-7} \mathrm{a}$ & $7.63 \times 10^{-5} \mathrm{a}$ & $2.81 \times 10^{-6} \mathrm{a}$ & $1.84 \times 10^{-3} \mathrm{~b}$ \\
\hline & & Swine manure & $7.05 \times 10^{-3} \mathrm{~b}$ & $1.12 \times 10^{-2} \mathrm{c}$ & $3.36 \times 10^{-7} \mathrm{a}$ & $6.77 \times 10^{-5} \mathrm{a}$ & $6.20 \times 10^{-6} \mathrm{a}$ & $2.62 \times 10^{-4} \mathrm{a}$ \\
\hline & & Cattle manure & $4.93 \times 10^{-4} \mathrm{a}$ & $1.43 \times 10^{-3} \mathrm{a}$ & $2.70 \times 10^{-7} \mathrm{a}$ & $1.64 \times 10^{-4} \mathrm{a}$ & $2.66 \times 10^{-6} \mathrm{a}$ & $2.93 \times 10^{-4} \mathrm{a}$ \\
\hline
\end{tabular}

Different lower-case letters indicate the results of multiple comparisons between different organic waste.

The trends of heavy metal exposure were the same for adults and children and can be ranked in decreasing order based on the mean values of ADD: $\mathrm{Zn}>\mathrm{Cr}>\mathrm{Cu}>\mathrm{Pb}>$ $\mathrm{As}>\mathrm{Cd}$ for sewage sludge and chicken manure, and $\mathrm{Zn}>\mathrm{Cu}>\mathrm{Cr}>\mathrm{Pb}>\mathrm{As}>\mathrm{Cd}$ for swine manure and cattle manure. Furthermore, the exposure trends of different kinds of 
heavy metals were the same for both adults and children. For $\mathrm{Cu}$ and $\mathrm{Zn}$, exposure can be ranked as swine manure $>$ chicken manure $>$ sewage sludge $>$ cattle manure; for As and $\mathrm{Cd}$, sewage sludge $>$ swine manure $>$ chicken manure $>$ cattle manure; for $\mathrm{Pb}$, sewage sludge $>$ cattle manure > chicken manure > swine manure; and for $\mathrm{Cr}$, sewage sludge $>$ chicken manure $>$ cattle manure $>$ swine manure. In sum, the magnitude of heavy metal exposure for both adults and children was consistent with the heavy metal content, but the exposure rates were higher for children than for adults. Differences between four kinds of organic wastes were the same as the status based on heavy metal contents according to the multiple comparisons.

\subsubsection{Non-Carcinogenic Risk Assessment}

The non-carcinogenic risk for adults and children based on heavy metal exposure in different kinds of organic waste is shown in Table 6. The ranking of heavy metals according to mean $\mathrm{HQ}$ values for adults and children was the same; they can be ranked in decreasing order as $\mathrm{Cr}>\mathrm{Cu}>\mathrm{Zn}>\mathrm{Pb}$ for sewage sludge and chicken manure and $\mathrm{Cu}>\mathrm{Cr}>\mathrm{Zn}>\mathrm{Pb}$ for swine and cattle manure. Multiple comparisons indicated that the non-carcinogenic risk caused by $\mathrm{Cu}$ and $\mathrm{Zn}$ exposure from swine manure was significantly different to that for other organic waste; the non-carcinogenic risk caused by $\mathrm{Pb}$ and $\mathrm{Cr}$ from sewage sludge was significantly different to that for other organic waste. Due to their high content and low $\mathrm{RfD}, \mathrm{Cr}$ and $\mathrm{Cu}$ had high non-carcinogenic risks for adults and children. $\mathrm{Zn}$, which had the highest content in all organic wastes, had a low non-carcinogenic risk as its RfD value was the highest. $\mathrm{Pb}$, which had the lowest content in all organic wastes and a large RfD value was shown to have the lowest non-carcinogenic risk among the four non-carcinogenic heavy metals.

Table 6. Non-carcinogenic risk for adults and children due to environmental exposure to heavy metals in sewage sludge and livestock manure for agricultural use.

\begin{tabular}{|c|c|c|c|c|c|c|}
\hline Kinds & Index & Organic Waste & $\mathrm{Cu}$ & Zn & $\mathrm{Pb}$ & $\mathrm{Cr}$ \\
\hline \multirow{16}{*}{ Adults } & \multirow{4}{*}{ HQ ingest } & Sewage sludge & $2.60 \times 10^{-2} \mathrm{a}$ & $1.74 \times 10^{-3} \mathrm{~b}$ & $7.27 \times 10^{-4} \mathrm{~b}$ & $4.95 \times 10^{-2} \mathrm{~b}$ \\
\hline & & Chicken manure & $2.93 \times 10^{-2} \mathrm{a}$ & $1.81 \times 10^{-3} \mathrm{~b}$ & $2.29 \times 10^{-4} \mathrm{a}$ & $4.21 \times 10^{-2} \mathrm{~b}$ \\
\hline & & Swine manure & $2.01 \times 10^{-1} \mathrm{~b}$ & $4.26 \times 10^{-3} \mathrm{c}$ & $2.04 \times 10^{-4} \mathrm{a}$ & $5.99 \times 10^{-3} \mathrm{a}$ \\
\hline & & Cattle manure & $1.41 \times 10^{-2} \mathrm{a}$ & $5.46 \times 10^{-4} \mathrm{a}$ & $4.95 \times 10^{-4} \mathrm{a}$ & $6.70 \times 10^{-3} \mathrm{a}$ \\
\hline & \multirow{4}{*}{$\mathrm{HQ}_{\text {inhale }}$} & Sewage sludge & $3.83 \times 10^{-6} \mathrm{a}$ & $2.56 \times 10^{-7} \mathrm{~b}$ & $1.07 \times 10^{-7} \mathrm{~b}$ & $7.27 \times 10^{-6} \mathrm{~b}$ \\
\hline & & Chicken manure & $4.30 \times 10^{-6} \mathrm{a}$ & $2.66 \times 10^{-7} \mathrm{~b}$ & $3.37 \times 10^{-8} \mathrm{a}$ & $6.19 \times 10^{-6} \mathrm{~b}$ \\
\hline & & Swine manure & $2.96 \times 10^{-5} \mathrm{~b}$ & $6.27 \times 10^{-7} \mathrm{c}$ & $2.99 \times 10^{-8} \mathrm{a}$ & $8.81 \times 10^{-7} \mathrm{a}$ \\
\hline & & Cattle manure & $2.07 \times 10^{-6} \mathrm{a}$ & $8.03 \times 10^{-8} \mathrm{a}$ & $7.27 \times 10^{-8} \mathrm{a}$ & $9.86 \times 10^{-7} \mathrm{a}$ \\
\hline & \multirow{4}{*}{ HQ } & Sewage sludge & $2.60 \times 10^{-2} \mathrm{a}$ & $1.74 \times 10^{-3} \mathrm{~b}$ & $7.27 \times 10^{-4} \mathrm{~b}$ & $4.95 \times 10^{-2} \mathrm{~b}$ \\
\hline & & Chicken manure & $2.93 \times 10^{-2} \mathrm{a}$ & $1.81 \times 10^{-3} \mathrm{~b}$ & $2.29 \times 10^{-4} \mathrm{a}$ & $4.21 \times 10^{-2} \mathrm{~b}$ \\
\hline & & Swine manure & $2.02 \times 10^{-1} \mathrm{~b}$ & $4.26 \times 10^{-3} \mathrm{c}$ & $2.04 \times 10^{-4} \mathrm{a}$ & $5.99 \times 10^{-3} \mathrm{a}$ \\
\hline & & Cattle manure & $1.41 \times 10^{-2} \mathrm{a}$ & $5.46 \times 10^{-4} \mathrm{a}$ & $4.95 \times 10^{-4} \mathrm{a}$ & $6.71 \times 10^{-3} \mathrm{a}$ \\
\hline & \multirow{4}{*}{$\mathrm{HI}$} & Sewage sludge & \multirow{4}{*}{\multicolumn{4}{|c|}{$\begin{array}{l}7.79 \times 10^{-2} \mathrm{a} \\
7.34 \times 10^{-2} \mathrm{a} \\
2.12 \times 10^{-1} \mathrm{~b} \\
2.18 \times 10^{-2} \mathrm{a}\end{array}$}} \\
\hline & & Chicken manure & & & & \\
\hline & & Swine manure & & & & \\
\hline & & Cattle manure & & & & \\
\hline \multirow{16}{*}{ Children } & \multirow{4}{*}{ HQ $Q_{\text {ingest }}$} & Sewage sludge & $2.28 \times 10^{-1} \mathrm{a}$ & $1.52 \times 10^{-2} \mathrm{~b}$ & $6.36 \times 10^{-3} \mathrm{~b}$ & $4.33 \times 10^{-1} \mathrm{~b}$ \\
\hline & & Chicken manure & $2.56 \times 10^{-1} \mathrm{a}$ & $1.58 \times 10^{-2} \mathrm{~b}$ & $2.01 \times 10^{-3} \mathrm{a}$ & $3.68 \times 10^{-1} \mathrm{~b}$ \\
\hline & & Swine manure & $1.76 \mathrm{~b}$ & $3.73 \times 10^{-2} \mathrm{c}$ & $1.78 \times 10^{-3} \mathrm{a}$ & $5.24 \times 10^{-2} \mathrm{a}$ \\
\hline & & Cattle manure & $1.23 \times 10^{-1} \mathrm{a}$ & $4.78 \times 10^{-3} \mathrm{a}$ & $4.33 \times 10^{-3} \mathrm{a}$ & $5.87 \times 10^{-2} \mathrm{a}$ \\
\hline & \multirow{4}{*}{$\mathrm{HQ}_{\text {inhale }}$} & Sewage sludge & $6.36 \times 10^{-6} a$ & $4.25 \times 10^{-7} \mathrm{~b}$ & $1.78 \times 10^{-7} \mathrm{~b}$ & $1.21 \times 10^{-5} \mathrm{~b}$ \\
\hline & & Chicken manure & $7.15 \times 10^{-6} \mathrm{a}$ & $4.41 \times 10^{-7} \mathrm{~b}$ & $5.61 \times 10^{-8} \mathrm{a}$ & $1.03 \times 10^{-5} \mathrm{~b}$ \\
\hline & & Swine manure & $4.93 \times 10^{-5} \mathrm{~b}$ & $1.04 \times 10^{-6} \mathrm{c}$ & $4.98 \times 10^{-8} \mathrm{a}$ & $1.46 \times 10^{-6} \mathrm{a}$ \\
\hline & & Cattle manure & $3.45 \times 10^{-6} \mathrm{a}$ & $1.33 \times 10^{-7} \mathrm{a}$ & $1.21 \times 10^{-7} \mathrm{a}$ & $1.64 \times 10^{-6} \mathrm{a}$ \\
\hline & \multirow{4}{*}{ HQ } & Sewage sludge & $2.28 \times 10^{-1} \mathrm{a}$ & $1.52 \times 10^{-2} \mathrm{~b}$ & $6.36 \times 10^{-3} \mathrm{~b}$ & $4.33 \times 10^{-1} \mathrm{~b}$ \\
\hline & & Chicken manure & $2.56 \times 10^{-1} \mathrm{a}$ & $1.58 \times 10^{-2} \mathrm{~b}$ & $2.01 \times 10^{-3} \mathrm{a}$ & $3.68 \times 10^{-1} \mathrm{~b}$ \\
\hline & & Swine manure & $1.76 \mathrm{~b}$ & $3.73 \times 10^{-2} \mathrm{c}$ & $1.78 \times 10^{-3} \mathrm{a}$ & $5.24 \times 10^{-2} \mathrm{a}$ \\
\hline & & Cattle manure & $1.23 \times 10^{-1} \mathrm{a}$ & $4.78 \times 10^{-3} \mathrm{a}$ & $4.33 \times 10^{-3} \mathrm{a}$ & $5.87 \times 10^{-2} \mathrm{a}$ \\
\hline & \multirow{4}{*}{$\mathrm{HI}$} & Sewage sludge & \multirow{4}{*}{\multicolumn{4}{|c|}{$\begin{array}{l}6.82 \times 10^{-1} \mathrm{a} \\
6.42 \times 10^{-1} \mathrm{a} \\
1.85 \mathrm{~b} \\
1.91 \times 10^{-1} \mathrm{a}\end{array}$}} \\
\hline & & Chicken manure & & & & \\
\hline & & Swine manure & & & & \\
\hline & & Cattle manure & & & & \\
\hline
\end{tabular}


For each type of organic waste, the contribution of heavy metals to non-carcinogenic risk for adults and children was the same. Based on mean $\mathrm{HQ}$ values, $\mathrm{Cu}, \mathrm{Zn}, \mathrm{Pb}$ and $\mathrm{Cr}$ accounted for $33.38 \%, 2.23 \%, 0.93 \%$ and $63.46 \%$ of the HI value for sewage sludge; $39.87 \%, 2.46 \%, 0.31 \%$ and $57.36 \%$ for chicken manure; $95.07,2.01,0.10$ and $2.83 \%$ for swine manure; and $64.54 \%, 2.50 \%, 2.26 \%$ and $30.70 \%$ for cattle manure. It can be seen from the results that $\mathrm{Cu}$ and $\mathrm{Cr}$ were the heavy metals that showed the highest correlation with non-carcinogenic risk. Although the $\mathrm{Zn}$ content in all four organic wastes was high, it had the lowest non-carcinogenic risk.

The values of $\mathrm{HQ}_{\text {ingest }}$ and $\mathrm{HQ}_{\text {inhale }}$ were less than one for all heavy metals; however, the $\mathrm{HQ}_{\text {ingest }}$ value of $\mathrm{Cu}$ for children was 1.76. This indicated no non-carcinogenic risk for adults and children exposed to heavy metals in sewage sludge and livestock manure via either ingestion or inhalation, but a non-carcinogenic risk for children exposed to $\mathrm{Cu}$ from swine manure via ingestion. The differential values of $\mathrm{HQ}_{\text {ingest }}$ and $\mathrm{HQ}_{\text {inhale }}$ showed that ingestion was the major pathway of heavy metal exposure from sewage sludge and livestock manure for adults and children, and inhalation had an almost negligible contribution.

Regarding the mean value, calculated HQ values were all less than one for adults and children for sewage sludge and all kinds of livestock manure, except for children exposed to swine manure. This indicates no non-carcinogenic risk for adults or children exposed to all organic wastes, except children exposed to swine manure. Furthermore, the HQ values were higher for children exposed to sewage sludge and livestock manure than adults, with the same heavy metal content.

As shown in Table 6, the HI values for adults and children were $7.79 \times 10^{-2}$ and 6.82 $\times 10^{-1}$ for sewage sludge, $7.34 \times 10^{-2}$ and $6.42 \times 10^{-1}$ for chicken manure, $2.12 \times 10^{-1}$ and 1.85 for swine manure, and $2.18 \times 10^{-2}$ and $1.91 \times 10^{-1}$ for cattle manure. For both adults and children, the $\mathrm{HI}$ values for swine manure were the highest and for cattle manure were the lowest. In the multiple comparisons, swine manure is significantly different from other organic wastes regarding non-carcinogenic risk. Furthermore, only the agricultural use of swine manure had a non-carcinogenic risk for children.

\subsubsection{Carcinogenic Risk Assessment}

The carcinogenic risk for adults and children exposed to agricultural sewage sludge and livestock manure was calculated, and results are shown in Table 7. The Risk values were higher for As than $\mathrm{Cd}$ for both adults and children based on the mean value, and they are all less than $1 \times 10^{-4}$. This indicated that the carcinogenic risk was higher for As than $\mathrm{Cd}$, and exposure to both heavy metals from sewage sludge and livestock manure did not generate a significant unacceptable carcinogenic risk for either adults or children. Furthermore, the Risk values for sewage sludge were between $1 \times 10^{-4}$ and $1 \times 10^{-6}$, suggesting that there was insignificant carcinogenic risk from the agricultural use of sewage sludge. Comparing the two pathways of As and Cd exposure for adults and children, ingestion was found to be the main source of carcinogenic risk based on higher Risk ingest than Risk inhale values [42]. In the multiple comparisons, the carcinogenic risk caused by As and $\mathrm{Cd}$ exposure from sewage sludge showed a significant difference from other organic wastes.

Furthermore, the mean RISK values, which represented the total carcinogenic risk of As and Cd, were less than $1 \times 10^{-5}$, except that for sewage sludge for adults and children and swine manure for children. This indicated that the agricultural use of chicken and cattle manure does not pose a carcinogenic risk to adults and children, but the use of sewage sludge would pose a carcinogenic threat to both adults and children and the use of swine manure would pose a carcinogenic risk to children only. Based on the mean RISK values of the total carcinogenic risk, the agricultural use of cattle and chicken manure was safer than the use of sewage sludge and swine manure. The multiple comparisons indicated that sewage sludge was significantly different from other organic waste regarding carcinogenic risk. 
Table 7. Carcinogenic risk for adults and children due to environmental exposure to heavy metals in sewage sludge and livestock manure for agricultural use.

\begin{tabular}{|c|c|c|c|c|c|c|c|c|}
\hline \multirow{2}{*}{ Kinds } & \multirow{2}{*}{ Organic Waste } & \multicolumn{3}{|c|}{ As } & \multicolumn{3}{|c|}{$\mathrm{Cd}$} & \multirow{2}{*}{ RISK } \\
\hline & & Risk $_{\text {ingest }}$ & Risk $_{\text {inhale }}$ & Risk & Risk $_{\text {ingest }}$ & Risk $_{\text {inhale }}$ & Risk & \\
\hline \multirow{4}{*}{ Adults } & Sewage sludge & $1.38 \times 10^{-5} \mathrm{~b}$ & $2.03 \times 10^{-9} \mathrm{~b}$ & $1.38 \times 10^{-5} \mathrm{~b}$ & $2.81 \times 10^{-6} \mathrm{~b}$ & $4.13 \times 10^{-10} \mathrm{~b}$ & $2.81 \times 10^{-6} \mathrm{~b}$ & $1.66 \times 10^{-5} \mathrm{~b}$ \\
\hline & Chicken manure & $2.41 \times 10^{-6} \mathrm{a}$ & $3.54 \times 10^{-10} \mathrm{a}$ & $2.41 \times 10^{-6} \mathrm{a}$ & $1.12 \times 10^{-6} \mathrm{a}$ & $1.64 \times 10^{-10} \mathrm{a}$ & $1.12 \times 10^{-6} \mathrm{a}$ & $3.52 \times 10^{-6} \mathrm{a}$ \\
\hline & Swine manure & $5.31 \times 10^{-6} \mathrm{a}$ & $7.81 \times 10^{-10} \mathrm{a}$ & $5.31 \times 10^{-6} \mathrm{a}$ & $1.17 \times 10^{-6} \mathrm{a}$ & $1.72 \times 10^{-10} \mathrm{a}$ & $1.17 \times 10^{-6} \mathrm{a}$ & $6.48 \times 10^{-6} \mathrm{a}$ \\
\hline & Cattle manure & $2.28 \times 10^{-6} \mathrm{a}$ & $3.35 \times 10^{-10} \mathrm{a}$ & $2.28 \times 10^{-6} \mathrm{a}$ & $9.41 \times 10^{-7} \mathrm{a}$ & $1.38 \times 10^{-10} \mathrm{a}$ & $9.41 \times 10^{-7} \mathrm{a}$ & $3.22 \times 10^{-6} \mathrm{a}$ \\
\hline \multirow{4}{*}{ Children } & Sewage sludge & $2.41 \times 10^{-5} \mathrm{~b}$ & $6.75 \times 10^{-10} \mathrm{~b}$ & $2.41 \times 10^{-5} \mathrm{~b}$ & $4.91 \times 10^{-6} \mathrm{~b}$ & $1.37 \times 10^{-10} \mathrm{~b}$ & $4.91 \times 10^{-6} \mathrm{~b}$ & $2.91 \times 10^{-5} \mathrm{~b}$ \\
\hline & Chicken manure & $4.21 \times 10^{-6} \mathrm{a}$ & $1.18 \times 10^{-10} \mathrm{a}$ & $4.21 \times 10^{-6} \mathrm{a}$ & $1.95 \times 10^{-6} \mathrm{a}$ & $5.45 \times 10^{-11} \mathrm{a}$ & $1.95 \times 10^{-6} \mathrm{a}$ & $6.16 \times 10^{-6} \mathrm{a}$ \\
\hline & Swine manure & $9.30 \times 10^{-6} \mathrm{a}$ & $2.60 \times 10^{-10} \mathrm{a}$ & $9.30 \times 10^{-6} \mathrm{a}$ & $2.05 \times 10^{-6} \mathrm{a}$ & $5.73 \times 10^{-11} \mathrm{a}$ & $2.05 \times 10^{-6} \mathrm{a}$ & $1.13 \times 10^{-5} \mathrm{a}$ \\
\hline & Cattle manure & $3.99 \times 10^{-6} \mathrm{a}$ & $1.11 \times 10^{-10} \mathrm{a}$ & $3.99 \times 10^{-6} \mathrm{a}$ & $1.65 \times 10^{-6} \mathrm{a}$ & $4.60 \times 10^{-11} \mathrm{a}$ & $1.65 \times 10^{-6} \mathrm{a}$ & $5.63 \times 10^{-6} \mathrm{a}$ \\
\hline
\end{tabular}

Different lower-case letters indicate the results of multiple comparisons between different organic waste.

\section{Discussion}

\subsection{Heavy Metals in Sewage Sludge and Livestock Manure}

The source of heavy metals in sewage sludge is anthropogenic activities [52]. Coking, mining, metallurgy and leather tanning located in the study area caused the $\mathrm{Zn}, \mathrm{Cr}, \mathrm{Cu}$, and $\mathrm{Pb}$ pollution of sewage sludge. Low level pollution of $\mathrm{As}$ and $\mathrm{Cd}$ in sewage sludge may be caused by households, such as by the use of detergents [35]. China's third-largest mining industry, located in the study area, would cause the content of $\mathrm{Cu}$ and $\mathrm{Zn}$ in sewage sludge to be significantly higher.

In raising livestock, heavy metals are widely added to fodder as feed additives to promote livestock growth and prevent disease [53]. Because the usage rate of heavy metals by livestock is low, they are mostly metabolized in the manure [21]. Cu is important for normal growth, $\mathrm{Zn}$ is essential for breeding and immunity [54], and $\mathrm{Cr}$ can improve growth performance and feed consumption and efficiency as well as can improve carcass quality and enhance body immunity [13,55]. Due to the vital function of $\mathrm{Cu}, \mathrm{Zn}$ and $\mathrm{Cr}$ for livestock raising, the content of these in livestock manure is greater now than in the 1990s [53]. In order to promote the growth of swine, more $\mathrm{Cu}$ and $\mathrm{Zn}$ are added to their feed, so the contents of $\mathrm{Cu}$ and $\mathrm{Zn}$ in swine manure are higher than those in other livestock manure. The highest content of $\mathrm{Cr}$ appears in chicken manure, due to the fact that $\mathrm{Cr}$ can improve the laying rate of chickens, prolong the peak period of laying, increase the egg weight, improve the egg quality and reduce the amounts of broken eggs [13].

In order to pursue the growth rate of livestock, enhance disease resistance and control animal physiological metabolism, many farms add excessive amounts of heavy metals, especially in $\mathrm{Cu}, \mathrm{Zn}$ and $\mathrm{Cr}$. This leads to contents of $\mathrm{Cu}, \mathrm{Zn}$ and $\mathrm{Cr}$ in chicken manure, swine manure and cattle manure that are greatly different in each farm [56]. Unlike swine and chickens, cattle are mainly fed with silage and grass; thus, the pollution of silage and grass would have a great influence on cattle manure [48,49].

\subsection{The Potential Ecological Risk}

Because of the complexity of sewage sludge and livestock manure, PI cannot reflect the potential ecological risk better than PN, which combines the pollution levels of all metals to accurately reveal the pollution levels of sewage sludge and livestock manure $[35,57,58]$.

The pollution of sewage sludge was caused mainly by $\mathrm{Zn}$, As, and $\mathrm{Cr}$ from nearby industries, such as mining, coking, metallurgy and leather tanning $[4,35,52,58]$. The pollution of chicken manure was caused mainly by $\mathrm{Zn}$ and $\mathrm{Cr}$, which are added to fodder to improve immunity and laying rate $[59,60]$. The pollution of swine manure was caused mainly by $\mathrm{Cu}$ and $\mathrm{Zn}$, which were added to feed to strengthen immunity and the metabolic rate, which is low for swine [61,62]. Cattle manure was the safest of the four organic wastes for agricultural use [49]. As found in other studies, heavy metal pollution of swine manure is higher than other livestock manure [56]. 


\subsection{The Human Health Risk}

Based on the same concentration, heavy metal exposure was higher for children than for adults; the adverse effects of heavy metal exposure in sewage sludge and livestock manure were more serious for children $[38,63]$. This may be due to the fact that children have a lower body weight than adults and engage in more outdoor activity than adults [39,63]. Comparing the two pathways of heavy metal exposure, the effect of inhaling was negligible, and ingesting was more prominent. This is in agreement with other studies $[39,46,63]$.

The non-carcinogenic risk for agricultural use of swine manure is greater than other organic wastes, and children have a higher non-carcinogenic risk from the agricultural use of swine manure. Compared with adults, children should receive more attention when they are exposed to the same contamination [42]. This suggests that children's capacity to deal with toxins is weaker than adults' when the toxin content is the same $[64,65]$.

Regarding carcinogenic risk, As is more effective than Cd [4]. Agricultural use of sewage sludge poses carcinogenic risk to both adults and children, and the use of swine manure poses carcinogenic risk to children only. This suggests that the RISK value is always higher for children than for adults and that children are more vulnerable to carcinogenic risk than adults if they are in the same polluted environment [64].

\section{Conclusions}

To compare the ecological and human health risks of using sewage sludge and livestock manure for agricultural use, samples were collected, and the heavy metals contained in them were determined. The contents of $\mathrm{Zn}, \mathrm{Cu}$ and $\mathrm{Cr}$ were high in sewage sludge and livestock manure; the highest content of $\mathrm{Cu}$ and $\mathrm{Zn}$ was in swine manure, and the lowest in cattle manure. Compared with the secondary Quality Control Standards of Imported Organic Fertilizers, the mean values of $\mathrm{Cu}$ in swine manure, $\mathrm{Zn}$ in sewage sludge, chicken manure, and swine manure, $\mathrm{Cd}$ and $\mathrm{Pb}$ in none of them, As in sewage sludge, and $\mathrm{Cr}$ in sewage sludge and chicken manure were higher than the threshold values.

Based on the mean PI values, $\mathrm{Cu}, \mathrm{Zn}$, As and $\mathrm{Cr}$ in sewage sludge and livestock manures all induced an ecological risk, and $\mathrm{Zn}$ in swine manure had a high contamination level. Based on mean PN values, organic waste can be ranked in the following order: swine manure $>$ chicken manure $>$ sewage sludge $>$ cattle manure.

The daily exposure of $\mathrm{Cu}, \mathrm{Zn}$ and $\mathrm{Cr}$ from sewage sludge and livestock manure was higher for both adults and children. Swine exposed the highest $\mathrm{Cu}$ and $\mathrm{Zn}$ and sewage sludge exposed the highest $\mathrm{Cr}$. Comparatively, heavy metal exposure for children was higher than adults, and ingestion was the main pathway. Based on the mean HQ values, $\mathrm{Cu}$ and $\mathrm{Cr}$ were the main heavy metals, causing non-carcinogenic risks for both adults and children. Based on the mean HI value, only children had a non-carcinogenic risk posed by swine manure, mainly via ingestion. For carcinogenic risk, As posed a higher risk than Cd for all organic waste. Combining the two carcinogenic heavy metals, sewage sludge for adults and children and swine manure for children present unacceptable carcinogenic risks based on RISK values higher than $1 \times 10^{-5}$. For both non-carcinogenic and carcinogenic risk, ingestion is the main pathway of heavy metal exposure for adults and children, and children are more sensitive than adults to the same pollutant exposure.

Comparing sewage sludge and livestock manure, cattle manure is the safest organic waste for agricultural use in terms of ecological and human health risk. Due to children's behavioral characteristics, they are more sensitive when they are in the same adverse environment as adults, so children should receive more attention to avoid the harmful effects of pollutants. Multiple comparisons suggested that swine manure was significantly different regarding potential ecological risk and non-carcinogenic risk, and sewage sludge was significantly different regarding carcinogenic risk.

Supplementary Materials: The following are available online at https:/ / www.mdpi.com/article / 10.3390 / toxics9070145/s1, Table S1: Analytical accuracy, precision, recovery and method detection limit; Table S2: Contents of heavy metals in sewage sludge and livestock manure $\left(\mathrm{mg} \cdot \mathrm{kg}^{-1}\right)$; Table S3: 
Heavy metal limits in sewage sludge and livestock manure for different criteria $\left(\mathrm{mg} \cdot \mathrm{kg}^{-1}\right)$; Table S4: Results of single-factor pollution index (PI) and Nemerow's synthetic pollution index (PN) for heavy metals in agricultural use of sewage sludge and livestock manure; Table S5: Average daily dose (ADD) of heavy metals in sewage sludge and livestock manure $\left(\mathrm{mg} \cdot \mathrm{kg}^{-1} \cdot \mathrm{day}^{-1}\right)$; Table S6: Non-carcinogenic risk for adults and children due to environmental exposure to heavy metals in sewage sludge and livestock manure for agricultural use; Table S7: Carcinogenic risk for adults and children due to environmental exposure to heavy metals in sewage sludge and livestock manure for agricultural use.

Author Contributions: B.D. and Q.F. conceived and designed the experiments; B.D. and Q.F. sampled and performed the experiments; Q.F. provided the analysis tools and technical assistance; B.D. and Q.F. analyzed the dates and wrote the paper. Both authors have read and agreed to the published version of the manuscript.

Funding: This research was funded by the National Natural Science Foundation of China (No. 41501201).

Institutional Review Board Statement: Not applicable.

Informed Consent Statement: Not applicable.

Data Availability Statement: The data presented in this study are available in the article and in the Supplementary Materials.

Conflicts of Interest: The authors declare no conflict of interest.

\section{References}

1. Mohamed, B.; Mounia, K.; Aziz, A.; Ahmed, H.; Rachid, B.; Lotfi, A. Sewage sludge used as organic manure in Moroccan sunflower culture: Effects on certain soil properties, growth and yield components. Sci. Total Environ. 2018, 627, 681-688. [CrossRef] [PubMed]

2. Schlegel, A.J.; Assefa, Y.; Bond, H.D.; Haag, L.A.; Stone, L.R. Changes in soil nutrients after 10 years of cattle manure and swine effluent application. Soil Till. Res. 2017, 172, 48-58. [CrossRef]

3. Ma, J.; Chen, Y.; Antoniadis, V.; Wang, K.; Tian, H. Assessment of heavy metal (loid)s contamination risk and grain nutritional quality in organic waste-amended soil. J. Hazard. Mater. 2020, 399, 123095. [CrossRef] [PubMed]

4. Duan, B.L.; Zhang, W.P.; Zhen, H.X.; Wu, C.Y.; Zhang, Q.Z.; Bu, Y.S. Comparison of health risk assessments of heavy metals and as in sewage sludge from wastewater treatment plants (WWTPs) for adults and children in the urban district of taiyuan, China. Int. J. Environ. Res. Public Health 2017, 14, 1194. [CrossRef]

5. Jiao, G.Y.; Liu, X.N.; Li, J.Z.; Zhang, Y.Q. The status report of livestock and poultry manure utilization in Shanxi. Anim. Ind. Environ. 2019, 9, 48-49.

6. $\quad$ Liu, J.Y.; Zhuo, Z.X.; Sun, S.Y.; Ning, X.A.; Zhao, S.Y.; Xie, W.M.; Wang, Y.J.; Zheng, L.; Huang, R.; Li, B. Concentrations of heavy metals in six municipal sludges from Guangzhou and their potential ecological risk assessment for agricultural land use. Pol. J. Environ. Stud. 2015, 24, 165-174. [CrossRef]

7. Fumagalli, M.; Perego, A.; Acutis, M. Modelling nitrogen leaching from sewage sludge application to arable land in the Lombardy region (northern Italy). Sci. Total Environ. 2013, 461, 509-518. [CrossRef]

8. Kendir, E.; Kentel, E.; Sanin, F.D. Evaluation of heavy metals and associated health risks in a metropolitan wastewater treatment plant's sludge for its land application. Hum. Ecol. Risk Assess. Int. J. 2015, 21, 1631-1643. [CrossRef]

9. Grotto, D.; Batista, B.L.; Souza, J.M.O.; Carneiro, M.F.H.; Santos, D.D.; Melo, W.J.; Barbosa, F., Jr. Essential and nonessential element translocation in corn cultivated under sewage sludge application and associated health risk. Water Air Soil Pollut. 2015, 226, 261. [CrossRef]

10. Mazurek, R.; Kowalska, J.; Gasiorek, M.; Zadroz'ny, P.; Józefowska, A.; Zaleski, T.; Kepke, W.; Tymczuk, M.; Orlowska, K. Assessment of heavy metals contamination in surface layers of Roztocze National Park forest soils (SE Poland) by indices of pollution. Chemosphere 2016, 168, 839-850. [CrossRef]

11. Li, S.D.; Sun, L.P.; Pan, X.H. Study on concentration and toxicity leaching of heavy metals in sludge from sewage treatment plants in Guangdong province. Chin. J. Health Lab. Tec. 2014, 24, 1763-1765.

12. Zhu, E.; Wang, Y.Q.; Lin, T.J.; Jin, H.Y.; Yang, X.L. Pollution characteristics of heavy metals in livestock manure in Shanghai. J. Agric. Resour. Environ. 2013, 30, 90-93.

13. Chen, M.; Cui, Y.S. A review on resource and bioavailability of heavy metals in biogas fertilizer from the manure of livestock. Chin. J. Soil Sci. 2012, 43, 249-256.

14. Nan, Z.R.; Zhao, C.Y. Heavy Metal Concentrations in Gray Calcareous Soils of Baiyin Region, Gansu Province, P.R. China. Water Air Soil Pollut. 2000, 118, 131-142. [CrossRef]

15. Kachout, S.S.; Mansoura, A.B.; Ennajah, A.; Leclerc, J.C.; Ouerghi, Z.; Bouraoui, N.K. Effects of metal toxicity on growth and pigment contents of annual halophyte (A. hortensis and A. rosea). Int. J. Environ. Res. 2015, 9, 613-620. 
16. Xu, Z.; Li, J.; Pan, Y.; Chai, X. Human health risk assessment of heavy metals in a replaced urban industrial area of Qingdao, China. Environ. Monit. Assess. 2016, 188, 1-12. [CrossRef] [PubMed]

17. He, X.W.; Fang, Z.Q.; Wang, Y.X.; Jia, M.Y.; Song, J.Y.; Cheng, Y.J. Pollution characteristics, potential ecological risk and health risk assessment of heavy metal in a sewage treatment plant in Beijing. Acta Sci. Circumstantiae 2016, 36, 1092-1098.

18. Mcbride, M.B. Toxic metals in sewage sludge-amended soils: Has promotion of beneficial use discounted the risks. Adv. Environ. Res. 2004, 8, 5-19. [CrossRef]

19. Sun, Y.B.; Zhou, Q.X.; Xie, X.K.; Liu, R. Spatial, sources and risk assessment of heavy metal contamination of urban soils in typical regions of Shenyang, China. J. Hazard Mater. 2010, 174, 455-462. [CrossRef] [PubMed]

20. Zhang, L.L.; Li, H.F.; Su, D.C. Characteristics and changes of heavy metals in sewage sludge of China. Res. Environ. Sci. 2013, 16, 313-319.

21. Nicholson, F.A.; Chambers, B.J.; Williams, J.R.; Unwin, R.J. Heavy metal contents of livestock feeds and animal manures in England and Wales. Bioresour. Technol. 1999, 70, 23-31. [CrossRef]

22. Van, W.S.; Prins, W.; Ronsse, F. Antal, M.J. Sewage sludge carbonization for biochar applications: Fate of heavy metals. Energy Fuels 2014, 28, 5318-5326.

23. Jolanta, L.; Kowalik, R.; Gawdzik, J. Risk Assessment of Soil Contamination with Heavy Metals from Municipal Sewage Sludge. Appl. Sci. 2021, 11, 548.

24. Tyta, M. Identification of the chemical forms of heavy metals in municipal sewage sludge as a critical element of ecological risk assessment in terms of its agricultural or natural use. Int. J. Environ. Res. 2020, 17, 4640. [CrossRef]

25. Birch, G.F. Determination of sediment metal background concentrations and enrichment in marine environments-A critical review. Sci. Total Environ. 2017, 580, 813-831. [CrossRef] [PubMed]

26. Kowalska, J.; Mazurek, R.; Gasiorek, M.; Setlak, M.; Zaleski, T.; Waroszewski, J. Soil pollution indices conditioned by medieval metallurgical activity-A case study from Krakow (Poland). Environ. Pollut. 2016, 218, 1023-1036. [CrossRef] [PubMed]

27. Qin, F.X.; Wei, C.F.; Zhong, S.Q.; Huang, X.F.; Pang, W.P.; Jiang, X. Soil heavy metal (loid)s and risk assessment in vicinity of a coal mining area from southwest Guizhou, China. J. Cent. South Univ. 2016, 23, 2205-2213. [CrossRef]

28. Kouidri, M.; Youcef, N.D.; Benabdellah, I.; Ghoubali, R.; Bernoussi, A.; Lagha, A. Enrichment and geoaccumulation of heavy metals and risk assessment of sediments from coast of Ain Temouchent (Algeria). Arab. J. Geosci. 2016, 9, 354. [CrossRef]

29. Yang, J.; Lei, M.; Chen, T.; Gao, D.; Zheng, G.D.; Guo, G.H.; Lee, D.J. Current status and developing trends of the contents of heavy metals in sewage sludges in China. Front. Environ. Sci. Eng. 2014, 8, 719-728. [CrossRef]

30. Fatoba, P.O.; Ogunkunle, C.O.; Folarin, O.O.; Oladele, F.A. Heavy metal pollution and ecological geochemistry of soil impacted by activities of oil industry in the Niger Delta, Nigeria. Environ. Earth Sci. 2016, 75, 297. [CrossRef]

31. Abrahim, G.M.; Parker, R.J. Assessment of heavy metal enrichment factors and the degree of contamination in marine sediments from Tamaki Estuary, Auckland, New Zealand. Environ. Monit. Assess. 2008, 136, 227-238. [CrossRef] [PubMed]

32. Mao, J.H. Practice and experience of compiling "Quality Control of Imported Organic Fertilizers". Agro. Environ. Prot. 1998, 17, 78-80.

33. Hakanson, L. An ecological risk index for aquatic pollution control, a sedimentological approach. Water Res. 1980, 14, 975-1001. [CrossRef]

34. Davis, H.T.; Aelion, C.M.; Mcdermott, S.; Lawson, A.B. Identifying natural and anthropogenic sources of metals in urban and rural soils using GIS-based data, PCA, and spatial interpolation. Environ. Pollut. 2009, 157, 2378-2385. [CrossRef]

35. Guo, G.H.; Chen, T.; Yang, J.; Zheng, G.; Ding, G. Regional distribution characteristics and variation of heavy metals in sewage sludge of China. Acta Sci. Circumstantiae 2014, 34, 2455-2461.

36. Yu, Y.J.; Sun, P.; Che, F.; Jia, X.F.; Xiang, M.D.; Wang, Q.; Guo, X.B. Development on health risks information management system of environmental pollution. J. Environ. Health 2011, 28, 622-625.

37. USEPA. A Guide to the Biosolids Risk Assessments for the EPA Part 503 Rule; U.S. Environmental Protection Agency Office of Wastewater Management: Washington, DC, USA, 1995.

38. Li, Z.Y.; Ma, Z.W.; van der Kuijp, T.J.; Yuan, Z.W.; Huang, L. A review of soil heavy metal pollution from mines in China: Pollution and health risk assessment. Sci. Total Environ. 2014, 468, 843-853. [CrossRef]

39. Yang, G.; Li, Y.; Wu, L.; Xie, L.P.; Wu, J. Concentration and health risk of heavy metals in topsoil of paddy field of Chengdu Plain. Environ. Chem. 2014, 33, 269-275.

40. USEPA. Risk Assessment Guidance for Superfund. Human Health Evaluation Manual, (Part A); Office of Emergency and Remedial Response: Washington, DC, USA, 1989.

41. USEPA. A Plain English Guide to the EPA Part 503 Biosolids Rule; U.S. Environmental Protection Agency Office of Wastewater Management: Washington, DC, USA, 1994.

42. Pan, L.; Ma, J.; Hu, Y.; Su, B.; Fang, G.; Wang, Y.; Wang, Z.S.; Wang, L.; Xiang, B. Assessments of levels, potential ecological risk, and human health risk of heavy metals in the soils from a typical county in Shanxi province, China. Environ. Sci. Pollut. Res. 2016, 23, 19330-19340. [CrossRef]

43. Praveena, S.M.; Ismail, S.N.S.; Aris, A.Z. Health risk assessment of heavy metal exposure in urban soil from Seri Kembangan (Malaysia). Arab. J. Geosci. 2015, 8, 9753-9761. [CrossRef] 
44. USEPA. Risk Assessment Guidance for Superfund Volume I: Human Health Evaluation Manual Supplemental, Guidance "Standard Default Exposure Factors" Interim Final; Office of Emergency and Remedial Response Toxics Integration Branch: Washington, DC, USA, 1991.

45. Muhammad, S.; Shah, M.T.; Khan, S. Health risk assessment of heavy metals and their source apportionment in drinking water of Kohistan region, Northern Pakistan. Microchem. J. 2011, 98, 334-343. [CrossRef]

46. Cao, S.Z.; Duan, X.L.; Zhao, X.G.; Ma, J.; Dong, T.; Huang, N.; Sun, C.Y.; He, B.; Wei, F.S. Health risks from the exposure of children to As, Se, Pb and other heavy metals near the largest coking plant in China. Sci. Total Environ. 2014, 472, 1001-1009. [CrossRef]

47. Pan, Y.; Tang, X.W.; Ji, P.H.; Yang, L.L.; Nguyen, T.H.; Tong, Y.A. The agricultural pollution risk estimation of livestock manure on heavy metals in Guanzhong Plain. China Environ. Sci. 2015, 35, 3824-3832.

48. Clemente, R.; Fuente, C.D.L.; Moral, R.; Bernal, M.P. Changes in microbial biomass parameters of a heavy metal-contaminated calcareous soil during a field remediation experiment. J. Environ. Qual. 2007, 36, 1137-1144. [CrossRef] [PubMed]

49. Qin, L.X.; Ma, J.W.; Sun, W.C.; Wang, F.; Lu, H.; Yu, Q.G.; Lin, H.; Fu, J.R. Characteristics of heavy metal and nutrient contents in livestock manure in Zhejiang Province. Acta Agric. Zhejiangensis 2015, 27, 604-610.

50. Przewrocki, P.; Kulczycka, J.; Wzorek, Z.; Kowalski, Z.; Gorazda, K.; Jodko, M. Risk analysis of sewage sludge-Poland and EU comparative approach. Pol. J. Environ. Stud. 2004, 13, 39-59.

51. Verdonck, O. International symposium on composting and use of composted material in horticulture. Compost. Specif. 1998, 469, 169-177.

52. Chen, T.B.; Zheng, Y.M.; Lei, M.; Huang, Z.C.; Wang, H.T.; Chen, H.; Fan, K.K.; Yu, K.; Wu, X.; Tian, Q.Z. Assessment of heavy metal pollution in surface soils of urban parks in Beijing, China. Chemosphere 2005, 60, 542-551. [CrossRef]

53. Liu, R.L.; Li, S.T.; Wang, X.B.; Wang, M. Contents of heavy metal in commercial organic fertilizer and organic wastes. J. Agro Environ. Sci. 2005, 24, 392-397.

54. Wang, Z.W.; Sun, J.G.; Sun, R.F.; Mao, H.X. Progress of biological function and application of trace element zinc. Feed. Res. 2005, 8, $12-16$.

55. Luo, X.G.; Guo, Y.L.; Liu, B.; Hao, Z.L.; Liu, J.L.; Gao, F.S.; Yu, S.X. Effect of dietary chromium on growth, serum biochemical traits and immune responses of broiler chicks during 0-3 weeks of age. Acta Vet. Et Zootech. Sin. 1999, 30, 481-489.

56. Zhang, F.S.; Li, Y.X.; Yang, M.; Li, W. Content of heavy metals in animal feeds and manures from farms of different scales in northeast China. Int. J. Environ. Res. Public Health 2012, 9, 2658-2668. [CrossRef] [PubMed]

57. Wu, J.G.; Zhao, Z.N.; Cai, Y.X. Analysis of chromium pollution for the leather processing industry. Environ. Impact Assess. 2015, 37, 64-77.

58. Facchinelli, A.; Sacchi, E.; Mallen, L. Multivariate statistical and GIS-based approach to identify heavy metal sources in soils. Environ. Pollut. 2001, 114, 313-324. [CrossRef]

59. Yang, L.; Xing, G.Z.; Zhang, L.Y.; Feng, M.S.; Niu, Y.B.; Yu, T.; Gong, W.Y.; Ma, X.1.; Wang, L.Z.; Lv, L.; et al. Analysis on heavy metal pollution in main feedstuffs for chicken in Hebei Province. China Poult. 2019, 41, $23-27$.

60. Fan, J.H.; Li, Q.H.; Zhang, L.; Zhang, Y.H. The flow of main nutrients and heavy metals in the feed of laying hens. J. Zhejiang Agric. Sci. 2020, 61, 217-220.

61. Chen, Z.Q.; Fu, Q.Q.; Cao, Y.S.; Wen, Q.X.; Wu, Y.Q. Effects of lime amendment on the organic substance changes, antibiotics removal, and heavy metals speciation transformation during swine manure composting. Chemosphere 2021, 262, 128342. [CrossRef] [PubMed]

62. Sheng, F.J.; Han, J.H.; Zhao, R.; Zhang, K.Q. Research on the contents and change characteristics of heavy metals in swine manure. J. Agric. Resour. Environ. 2020, 8, 0349.

63. Che, F.; Yu, Y.J.; Hu, C.; Yang, X.N.; Duan, X.L.; Li, Q.; Lin, H.P. Preliminary health risk assessment of heavy metals in soil in Shen-fu irrigation area. J. Agro Environ. Sci. 2009, 28, 1439-1443.

64. Yang, M.; Teng, Y.; Ren, W.J.; Huang, Y.; Xu, D.F.; Fu, Z.C.; Ma, W.T.; Luo, Y.M. Pollution and health risk assessment of heavy metals in agricultural soil around Shimen Realgar Mine. Soils 2016, 48, 1172-1178.

65. Diami, S.M.; Kusin, F.M.; Madzin, Z. Potential ecological and human health risks of heavy metals in surface soils associated with iron ore mining in Pahang, Malaysia. Environ. Sci. Pollut. Res. 2016, 23, 1-12. [CrossRef] [PubMed] 